\title{
Poverty, Inequality and Rising Growth in Nigeria: Further Empirical Evidence
}

\author{
Bashir Olayinka Kolawole ${ }^{1}$, Olufunsho Abayomi Omobitan ${ }^{1} \&$ Jameelah Omolara Yaqub $^{1}$ \\ ${ }^{1}$ Department of Economics, Faculty of Social Sciences, Lagos State University, Ojo, Lagos, Nigeria \\ Correspondence: Bashir Olayinka Kolawole, Department of Economics, Lagos State University, P.M.B 0001, \\ LASU Post Office, Ojo, Lagos State, Nigeria. Tel. 234-806-663-7927. E-mail: kolawolebashir@gmail.com
}

Received: November 11, 2014

Accepted: December 12, 2014

Online Published: January 25, 2015

doi:10.5539/ijef.v7n2p51

URL: http://dx.doi.org/10.5539/ijef.v7n2p51

\begin{abstract}
This study examines the relationship among poverty, inequality and economic growth in Nigeria by employing macroeconomic variables which include GDP growth rate, per capita income, literacy rate, government expenditure on education, and government expenditure on health. Time series data over the period from 1980 to 2012 were fitted into the Ordinary Least Square (OLS) regression equations using various econometric techniques such as Augmented Dickey Fuller (ADF) unit root test, Phillips-Perron unit root test, Johansen co-integration test, and Error Correction Mechanism (ECM) technique. The OLS results reveal that GDP growth rate increases inequality, but reduces poverty in the country. It is thus suggested that, aside boosting the GDP, an increased effective government spending on education and public health facilities, as well as programmes that are meant primarily for the non-privileged like children, women and the poor in general, be provided for poverty and inequality to reduce in the country.
\end{abstract}

Keywords: economic growth, headcount ratio, inequality, per capita income, poverty, co-integration

\section{Introduction}

It is a known fact that income inequality is paramount when it comes to making progress on poverty reduction. Income inequality matters greatly as it may slow down overall economic growth (Alesina \& Rodrik, 1994; Persson \& Tabellini, 1994; Alesina \& Perotti, 1996) and slow down the pace at which growth translates into poverty reduction (Kakwani, 1993; Bourguignon, 2004). A situation of high and rising inequality in the presence of increasing growth can only result into little or no reduction in the level of poverty (see Addison \& Cornia, 2001). According to Kim (2014), if all the growth recorded by countries continued at the same rate as over the last 20 years with income distribution remaining unchanged, poverty will only fall by 10 per cent by 2030 , from 17.7 per cent in 2010. It is further noted that increased income inequality can dampen the impact of growth in reducing poverty, such that inequality is not just a problem in itself.

As a group in 2006, United Nations Economic Commission for Africa (2007) reported that oil-exporting countries in Africa had the highest growth rates and contributed 57.5 per cent of the continent's 5.7 per cent growth rate. Yet the growth pattern in such countries is usually not socially inclusive as it benefits mostly the owners of a small number of large enterprises and not resulting in a significant increase of formal employment. In corroboration, data from the Central Intelligence Agency's World Factbook showed that 23.9 percent of the working population in Nigeria is unemployed, as an estimated 62 percent of the nation's 177 million people are below the age of 25. In 2011, 63 per cent of the population lived on less than USD 1 per day, up from 61 per cent in 2010. According to African Economic Outlook (2012), there seems to be little prospect that Nigeria will meet the Millennium Development Goal (MDG) target of cutting the number of people living in extreme poverty by the United Nations' 2015 deadline. The widely-used Gini coefficient for measuring inequality increased from 0.43 in 2004 to 0.48 .8 in 2010 even though the country's economy has expanded 6 percent a year since 2006 (see World Bank, 2014). However, the paradox of growth in Nigeria is that as the country gets richer; more of its citizens live in poverty. In 2012, the poverty survey by the Nigerian statistics agency showed that 61 percent of Nigerians were living on less than a dollar a day in 2010, up from 52 percent in 2004 (see Magnowski, 2014). World Bank (2001), World Development Report ranked Nigeria as the 28th poorest country in the world. But currently the country is listed among the top five countries in terms of number of poor. Although the boost to GDP may improve the investment outlook for the country, social progress is yet, slow. 
Meanwhile, in the attempt to improve the living standard of the people, several socio-economic programmes were introduced and implemented at different periods by successive governments in Nigeria. The paramount objective of the programmes was amongst others to reduce, and possibly eradicate poverty that has ravaged the country for decades since independence and in so doing, reduce the inequality between the rich and poor. As follow-up, many discussions on the effect of growth on poverty and inequality in the country had come up in studies which include Dauda (2004), Aigbokhan (2008) and Kolawole and Omobitan (2014). Most of the conclusions, however, point to the fact that an average Nigerian is still worse off such that there is widening gap between the haves and have-nots in the country. Also, each of these studies has either looked at factors affecting poverty, or those that impact on income inequality. Such that, to the best of our knowledge, there is no study that has quantitatively analysed poverty and income inequality first separately and, second jointly on how income inequality impacts on poverty in Nigeria. Thus, in furtherance to the discussion, the present study contributes by examining the extent to which per capita income, literacy rate and government expenditure on education and health have impacted on the poverty headcount ratio of population living below USD 1.25 per day in Nigeria. In essence, the study intends proffering relevant policy recommendations that would assist the government in reducing poverty and inequality as economic growth keeps improving in the country.

The remaining part of the study proceeds with section two stylizing some facts on government's efforts at reducing poverty and inequality in Nigeria; section three briefly reviews the literature; as methodology is explained in the fourth section; empirical results are presented and discussed in section five; while the sixth section concludes with recommendations.

\section{Stylized Facts}

In the efforts to reduce poverty and inequality in Nigeria, several agencies and schemes were established to tackle poverty and unemployment. These include the National Directorate of Employment, the National Poverty Eradication Programme, the Small and Medium Enterprises Development Agency and the Microcredit and Entrepreneurship Development schemes. The major policy issue is employment generation, particularly among the youth, and inclusive growth. Concerning job creation, the Community Services and Women and Youth Employment Programmes of the Subsidy Reinvestment and Development Programme (SURE-P) are already up and running in 14 states, with a target of creating 370,000 jobs per year.

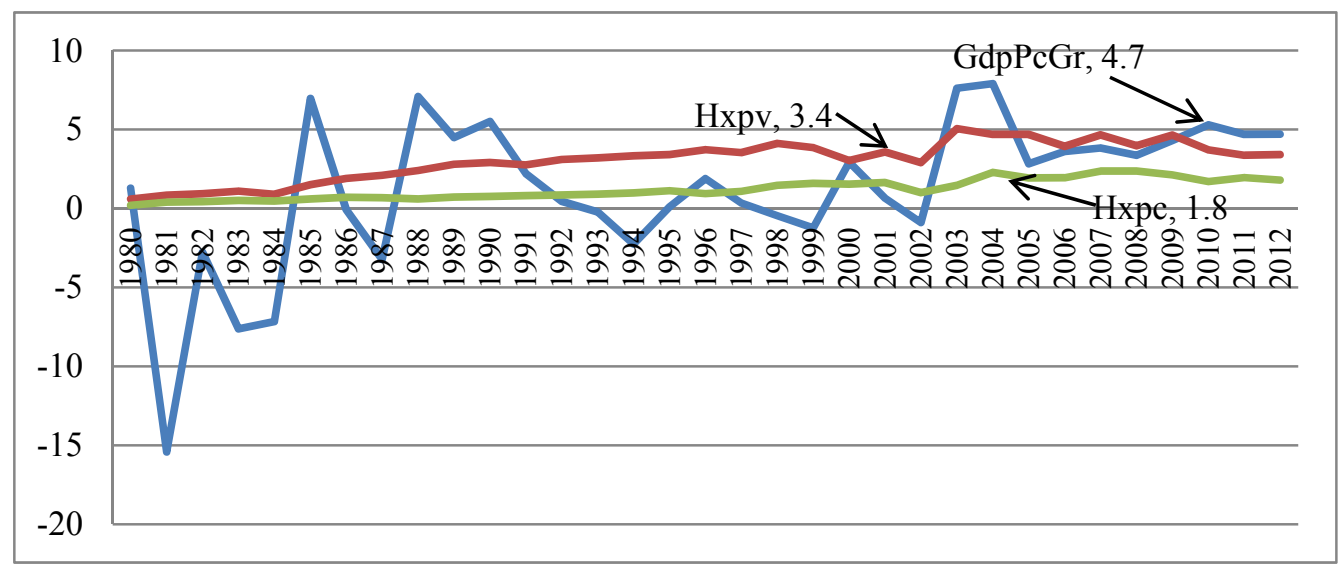

Figure 1. Trends in GDP per capita growth rate, public and private health expenditure

Source: Author's representation with data from World Bank (2014).

With respect to health, significant progress has been made over the last decade. The infant mortality rate moderated to 75 per thousand live births in 2008 from 110 per thousand in 2007. Maternal mortality was reduced to 545 per one hundred thousand births in 2008 from 800 per one hundred thousand live births. This, however, was with significant geopolitical dierentials. For example, the North East zone recorded a Maternal Mortality Ratio (MMR) of 1, 545 per one hundred thousand, while the South West zone recorded an MMR as low as 165 per one hundred thousand. In response to accelerating progress in MMR, the government has launched the UN MDG Acceleration Framework (MAF) for MDG 5. It draws attention to prioritised intervention, identifying and removing bottlenecks that impede the implementation of action plans. 
Also, the federal government has initiated three social protection initiatives: conditional cash transfers targeted at households with specific social characteristics, health fee waivers for pregnant women and children under five and community-based health insurance plans. Nevertheless, as depicted in Figure 1, private expenditure on health, over the years, has always been relatively more than the amount expended by government on health.

Recently, in consistence with the objectives of its Transformation Agenda, the government is investing in key sectors of the economy. In 2012, investment share to the education was 8.65 per cent while health had 6 per cent. The investment on education, however, relatively peaked in 2010 as represented in Figure 2. Also, security, power, agriculture and development, and public works got 19.9 per cent, 3.5 per cent, 1.7 per cent and 3.9 per cent, respectively.

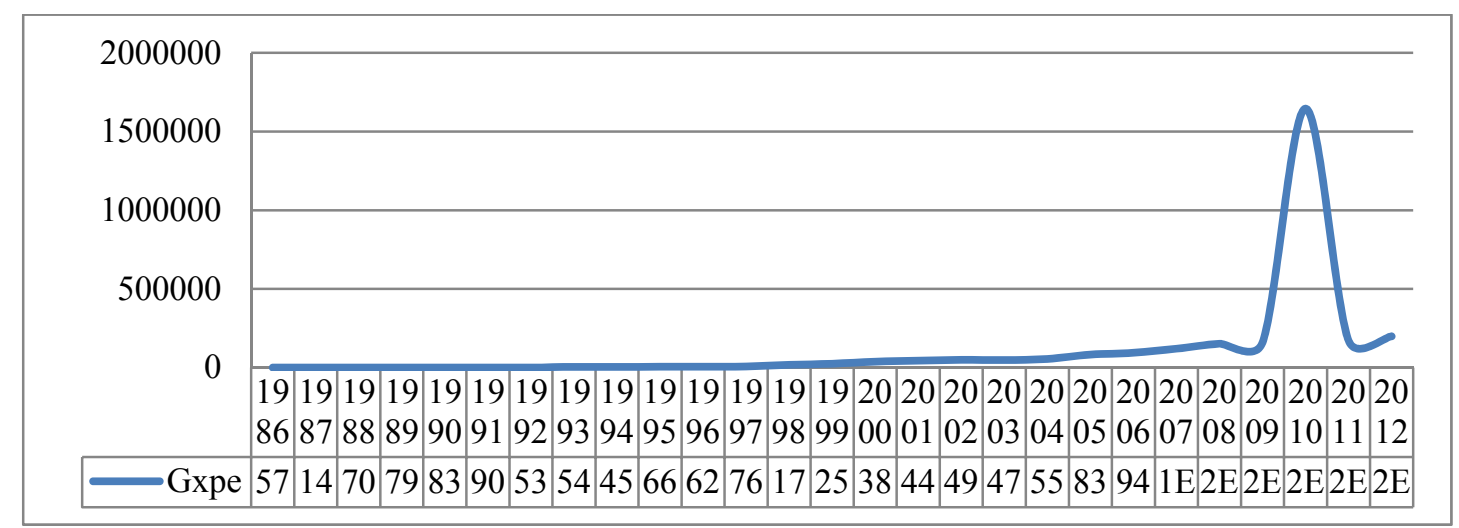

Figure 2. Trend of government expenditure on education

Source: Author's representation with data from Central Bank of Nigeria (2013).

As part of the human development policy, the country's MDG target for education is universal primary education and gender equality at primary and secondary levels. In this regard, a major development in education is the implementation of Universal Basic Education Programme. As a result, primary school enrolment increased to 89 per cent in 2005 from 80 per cent in 2004. The completion rate, however, is only at 68 per cent with a lot of out-of-school children. According to the Ministry of Education, Nigeria has over 10 million out-of-school children, or 42 per cent of the school-going population.

In May 2012, the president inaugurated the Agriculture Transformation Implementation Council (ATIC), with the mandate of driving the Agricultural Transformation Agenda (ATA). The ATA is a major tool for driving rural income growth, accelerating the achievement of food and nutritional security, generating employment and transforming the economy into a leading player in the global food market. The target is to create about 3.5 million new jobs from rice, cassava, sorghum, cocoa and cotton value chains, with many more jobs from other future value chain activities. It is also anticipated that farmers and other rural entrepreneurs might earn over NGN 300 billion in additional income from value chain activities, helping to reduce poverty. The expectation is that the widening gap between the rich and poor will decrease given the information in Table 1 where, in 2010, the share of income held by the highest 10 per cent was 38.23 as against 1.75 held by the lowest 10 per cent. Also, the Table shows a clear disparity in the trends of income distribution as the share of the highest 20 per cent increased from 45.01 in 1986 to 54.01 in 2010 while that of the lowest 20 per cent decreased from 6.02 per cent to 4.41 per cent in the same period, respectively. The Gini coefficient grew larger to 48.83 in 2010 from 38.68 in 1986.

Table 1. Income distribution and share held by subgroup of population

\begin{tabular}{cccccc}
\hline Year & Gini & Highest $10 \%$ & Lowest $10 \%$ & Highest $20 \%$ & Lowest $20 \%$ \\
\hline 1986 & 38.68 & 28.21 & 2.47 & 45.01 & 6.02 \\
1992 & 44.95 & 31.53 & 1.42 & 49.37 & 4.00 \\
1996 & 46.5 & 37.1 & 1.89 & 52.11 & 5.00 \\
2004 & 42.93 & 32.42 & 1.99 & 48.61 & 5.13 \\
2010 & 48.83 & 38.23 & 1.75 & 54.01 & 4.41 \\
\hline
\end{tabular}

Source: World Bank, Development Research Group (2014). 


\section{Review of Literature}

The relationship subsisting between poverty and growth; between income inequality and growth; between poverty and income inequality; and among poverty, income inequality and growth, is vast in the literature of development. Focusing on poverty-inequality nexus, Son (2007) is of the opinion that the elasticity of inequality should always be positive since a decrease in income inequality should decrease poverty. Ordinarily, changes in income distribution exacts larger effects on measures of the depth and severity of poverty as White \& Anderson (2001) observed that small changes in income distribution can have a large effect on poverty headcount. Essentially, a positive and significant effect between the two phenomenons was reported in single-country studies which include Wodon (1999) for Bangladesh; Lombardo (2008) for Italy; and Deolalikar (2002) for Thailand, where it was established that poverty level increases as the gap between income-group becomes larger. For Bangladesh, Wodon (1999) precisely asserts that poverty decreased significantly over the years, especially in urban areas, but inequality increased as well, so that the gains from growth for the poor were not as large as they would have been with a stable distribution. It was, therefore, established that the correlation between growth and inequality was much higher in urban than in rural areas. Also, the study demonstrates, via simulation, that higher growth does not reduce poverty much more than baseline growth as long as high savings rate are needed for achieving higher growth. Only in the long run does higher growth generate large gains in poverty reduction once consumption as a share of GDP rises.

Specifically, for Pakistan, Ali and Tahir (1999) and Cheema and Sial (2012) reported a positive link between the variables such that poverty and inequality move in the same direction. Similar effects have also been reported in cross-country studies by Ravallion and Chen (1997); Adams (2004); Ram (2007); Kanbur (2008); Fosu (2009, 2010); and Anyanwu \& Erhijakpor (2010). While testing the claim that in recent times the poor have lost ground, both relatively and absolutely, even when average levels of living have risen, Ravallion and Chen (1997) used household surveys for 67 developing and transitional economies over 1981-1994. The study finds that changes in inequality and polarization were uncorrelated with changes in average living standards. It was further revealed that distribution improved as often as it worsened in growing economies, and negative growth was often more detrimental to distribution than positive growth. In conclusion, given diverse experiences across regions and countries, poverty fell with increased average living standards and rose with contraction. On the emphasis that most of the well-known and influential recent researches seem to have overstated the impact of income growth on poverty alleviation by de-emphasising the role of inequality, to which poverty is highly responsive, Ram (2007) used an income (growth) elasticity of poverty to show the highly significant roles of income and equality in poverty reduction. The study further established that the elasticity of poverty with respect to inequality is substantially larger than that relative to income. However, the effects of increased income and lower inequality are both substantial.

Employing global sample of unbalanced panel data for the period from 1977 to 2004, Fosu (2009) explores the extent to which inequality affects the impact of income growth on the rates of poverty changes in sub-Saharan Africa (SSA) compared to non-SSA. The study finds the impact of GDP growth on poverty reduction to be a decreasing function of initial inequality. Although the impacts are similar in direction for both regions, the considerable disparities in the responsiveness of poverty to income growth, however depends on inequality. Nevertheless, according to the study, income-growth elasticity is substantially less for SSA, which implies relatively low poverty-reduction sensitivity to growth compared with the rest of the developing world. Thus, the paper concludes that there is a need to understand country-specific inequality attributes for poverty-reduction strategies to be effective as results reveal a considerable variation in the predicted values of income-growth elasticity across a large number of SSA countries. Deininger \& Squire (1996), however, have earlier argued that, on the average, within country income inequality is stable overtime, or changes too slowly to make a significant difference on poverty reduction.

As regard the relationship between income inequality and economic growth, results of empirical studies have produced different views. In the first view, the belief shows that inequality is not a final outcome of growth but plays a central role in determining the rate and pattern of growth (see Bourguignon, 2004). The view established that initial inequality seems to be empirically associated with lower growth rates. In appreciation of the view is the fact that rising income inequality matters, notably via its potential impact on economic growth as discussed, for instance, by Atkinson (1997). Along this thought, Ghosh and Pal (2004) show an ambiguous relationship between initial inequality and subsequent economic growth in India. The analysis suggests that rural inequality influences growth of total output more than urban inequality, and it does so negatively. Also, Ncube, Anyanwu and Hausken (2013) found that income inequality levels indeed significantly reduced economic growth as greater inequality was associated with lower economic growth in the MENA region. Studies whose results 
corroborate this view include Galor and Zeira (1993); Perotti (1993); Alesina and Rodrik (1994); Persson and Tabellini (1994); Birdsall, Ross and Sabot (1995); Clarke (1995); Alesina and Perotti (1996); De la Croix and Doepke (2003); Josten (2003, 2004); Ahituv and Moav (2003); Viaene and Zilcha (2003); Castelló-Climent (2004); Knowles (2005); Davis (2007) and Pede, Florax and Partridge (2009). In another view, Kaldor (1956); Partridge (1997); Li and Zou (1998); Forbes (2000); and Nahum (2005) converged on the opinion that income inequality leads to economic growth. According to Li and Zou (1998), income inequality may theoretically lead to higher economic growth if public consumption enters the utility function. In the empirical study, however, the baseline estimations and a sensitivity analysis show that income inequality is positively, and most of the time significantly, associated with economic growth. These findings, to a large extent, contrast the negative association between inequality and growth propounded by Alesina and Rodrik (1994) and by Persson and Tabellini (1994).

However, in the results reported by Barro (2000), the effect of income inequality on economic growth may differ in developed and developing economies, somewhat in line with the Kuznets curve; whereby inequality first increases and later decreases during the process of economic development. On the contrary, Kraay (2002) shows that growth does not have an increasing effect on income inequality. Yet, Charles-Coll (2013) concludes that Lee and Roemer (1998); Castelló and Domenech (2002); and Panizza (2002) found no correlation or an inconclusive evidence of any correlation between income inequality and economic growth.

One of the lessons of history is that poverty cannot be reduced except there is growth in the economy. Thus, economic growth is important for sustained progress on poverty reduction. Empirical evidences show that countries that have reduced poverty are the ones that have grown the fastest. Poverty, on the other hand, has grown fastest in countries that have stagnated economically. Corroborating this thought, Kakwani (1993) finds poverty to be highly sensitive to economic growth in Cote d'Ivoire and, is expected to decrease faster than the economic growth rate provided the growth process does not lead to an increase in income inequality. However, according to the study, if inequality deteriorates during the course of a country's economic growth, poverty may even increase with economic growth, because poverty measures were found to be considerably more elastic for changes in inequality. Results from the study further suggested that the smaller the poverty threshold, the greater the relative sensitivity of poverty is for changes in income inequality than for changes in the mean income. The study, therefore, concludes that the ultra poor are considerably more affected by the changes in income inequality than by changes in mean income. Essentially, however, income inequality could be harmful to poverty reduction and growth as Kurita and Kurosaki (2007) reported for Philippines and Thailand. In a similar case for Nigeria, Kolawole and Omobitan (2014) found a negatively significant effect of growth on poverty: as growth increases, poverty declines in the country.

\section{Methodology}

The ordinary least square (OLS) technique is adopted in this study. However, in the attempt to establish the poverty-inequality-growth nexus in Nigeria, two separate linear equations were estimated. The first equation examines the impacts of growth rate, literacy rate, government expenditure on education, and government expenditure on health, on per capita income in the country. While the second equation determines the effects of per capita income, growth rate, literacy rate, government expenditure on education, and government expenditure on health, on poverty headcount ratio. Furthermore, econometrics methodology of co-integration and error correction mechanism (ECM) were also employed. The stationarity of the data series was carried out through the both of the Augmented Dickey-Fuller (ADF) unit root test (Dickey \& Fuller, 1979) and the Phillips-Perron (PP) unit root test. These were confirmed at first difference as depicted in Table 2 thereby implying an I(1) series. The Johansen method was adopted in testing for cointegration among the variables and confirms the possibility of a long-run relationship among the variables. According to this approach, the lag length of the VAR must first be determined and this should be small enough to allow for estimation and, high enough to ensure that errors are approximately of white noise. As such, using five different information criteria viz: sequential modified LR test Statistic (LR), final prediction error (FPE), Akaike information criterion (AIC), Schwarz information criterion (SC), and Hannan-Quinn information criterion (HQ), it was concluded that the optimal lag length for the series was two (2) as shown in Table A1. Also, as depicted in Table A2, the results of the trace and maximal Eigenvalue of the unrestricted cointegration rank test indicate three (3) cointegrating equations at the 5 per cent level of significance. Afterwards, the error correction technique (ect) was extracted for the eventual construction of the parsimonious models. Due to the different units of measurement, and for the reason of clarity of interpretation of empirical results, the variables were transformed to their natural logarithms. More importantly, because of the fact that most of the socio-economic programmes of concerned were introduced and implemented prior to, during and after the structural adjustment programme (SAP), the series covered the period from 1980 to 2012. 


\subsection{Variable Description and Data Sources}

The variables employed in this study resulted from the indirect approach or income method discussed in Ravallion, Chen and Sangraula (2008). The idea in this approach is that, given the indicators of poverty, the poverty headcount ratio (phr) at $\$ 1.25$ a day (PPP) (per cent of population) is the proxy for poverty. The measures of income inequality are mainly the Lorenz curves and the Gini coefficient. The Gini coefficient measures income inequality based on the Lorenz curve and it varies from 0 (perfect equality) to 1 (perfect inequality). A Lorenz curve plots the cumulative percentages of total income received against the cumulative number of recipients, starting with the poorest individual or household. The Gini index measures the area between the Lorenz curve and a hypothetical line of absolute equality, expressed as a percentage of the maximum area under the line. The major limitation of these measures of inequality is that both neither indicate the number of people who fall below the poverty line nor the extent of impoverishment (Anyanwu, 1997), and the scarcity of their time-series data for Nigeria. Hence, per capita income (pci) is employed as measure of inequality.

Government expenditure on education (gxpe) and health (gxph) are also variables that determine the level of inequality and could individually reduce poverty as each stimulates effective demand in an economy. On this, the International Monetary Fund and the World Bank often divide public spending into three broad categories: economic spending, social spending, and other spending. Economic spending covers sectors like agriculture and infrastructure, while social spending includes health, education, nutrition, and social safety nets. Essentially, the social type is designed to build human and physical capital that will have long-term impact on economic growth, and therefore income, income distribution, and poverty. Typically, investment in this type also contributes to poverty reduction in the short run through increased demand for intermediate inputs, labour, and other factors of production. According to Anyanwu and Erhijakpor (2010), evidence has shown that expenditures for education and health are effective levers of redistribution. More importantly, when public spending on education as well as on health is targeted toward the poor, it can produce a double dividend, reducing inequality and poverty in the short run and increasing the chances for poor children to access formal jobs and thus break free from the intergenerational poverty trap.

Literacy rate also determines the levels of poverty and the distribution of income in an economy. Improving access to education, for example, can reduce inequality (and hence poverty) both by increasing individual productivity and by facilitating the movement of poor people from low-paying jobs in agriculture to higher-paying jobs in industry and services. Along this view, policymakers usually argue that efforts in the educational field reduce income inequality. Such that the higher the literacy rate, the more skewed is the distribution of income towards an individual or group and, the lower the level of poverty. Findings also indicate that education inequality is associated with lower investment rates and, consequently, lower income growth. Countries that showed greater inequality in the distribution of education have experienced lower investment rates than countries which showed less inequality. Therefore, policies which are formulated to promote growth should not only take into account the level but also the distribution of education, by generalising the access to formal education at different stages to a wider section of the population (see Castello \& Domenech, 2002).

GDP growth rate (gdpgr) is yet another variable that influences the levels of poverty and income inequality. It is the annual percentage growth rate of GDP whose aggregates are based on constant 2000 U.S. dollars. GDP is the sum of gross value added by all resident producers in the economy plus any product taxes and minus any subsidies not included in the value of the products. It is calculated without making deductions for depreciation of fabricated assets or for depletion and degradation of natural resources. This variable could alleviate an individual's poverty headcount ratio. Data for phr, pci, gdpgr, lit, gxpe and gxph were obtained from World Bank development research group and the Central Bank of Nigeria.

\subsection{The Models}

In the attempt to examine the relationship between inequality (per capita income) and growth, the study follows Barro (2000) and Gregorio and Lee (2002) on the factors which determine income inequality in their model specified in the form:

$$
G_{t}=\alpha_{0}+\alpha_{1} X_{t}+\alpha_{2} X_{t}^{2}+\alpha_{3} Z_{t}+e_{t}
$$

where $G_{t}$ is the Gini index for income inequality, $X_{t}$ is the natural logarithm of GDP per capita, and $Z_{t}$ is a vector of macroeconomic variables. Thus, in order to empirically capture the individual effects of GDP growth rate (Gdpgr), literacy rate (Lit), government expenditure on education (Gxpe) and government expenditure on health (Gxph) on per capita income (Pci), following Fan (2008a, 2008b) and Badiane and Ulimwengu (2009) on the link among poverty, income distribution, literacy rate, education and health expenditures, the re-specification of (1) in the functional and the natural log linear transformation forms are stated below respectively in (2) and (3) 
as:

$$
\begin{aligned}
& P c i_{t}=f\left(G d p g r_{t}, \text { Lit }_{r}, \text { Gxpe }_{t}, \text { Gxph } h_{t}\right) \\
& \ln P c i_{t}=\alpha_{o}+\alpha_{1} \ln G d p g r_{t}+\alpha_{2} \ln L i t_{t}+\alpha_{3} \ln G x p e_{t}+\alpha_{4} \ln G x p h_{t}+\varepsilon_{t}
\end{aligned}
$$

Furthermore, in the process of establishing the relationship among poverty, inequality and growth, the study theoretically follows Ravalion et al (2008) who postulate that the poverty line used in a given country is in fact the "social subjective poverty line" (SSPL) for that country. This, in the empirical implementation, allows for a country-specific error term, encompasses idiosyncratic differences in the data and methods used as well as measurement errors. It assumes that each individual has a subjective (personal) poverty line (z) which depends on own consumption or income (y). Also, the relationship is specific to a given setting (country or place) and, quite generally, one can postulate that the functional form relating $\mathrm{z}$ to $\mathrm{y}$ is country specific. As such, considering the country at large, it can further be postulated that the relationship depends on mean consumption (C), which is taken to capture the social effect on personal subjective poverty lines. The relationship is expressed as:

$$
z=\varphi(y, C) \text { for } y \in\left[y^{\min }, y^{\max }\right]
$$

Thus, at the empirical front, the study follows Cervantes-Godoy and Dewbre (2010) on the relationship among growth, poverty and inequality. The below modified specifications in functional form, as well as in the natural log linear transformation form in equations (5) and (6) respectively show the relationship, and capture the average impact of per capita income, GDP growth rate, literacy rate, government expenditure on education, and government expenditure on health on poverty headcount ratio.

$$
\begin{aligned}
& \text { Phr }_{t}=f\left(\text { Pci }_{t}, \text { Gdpgr }_{t}, \text { Lit }_{t}, \text { Gxpe }_{t}, \text { Gxph }_{t}\right) \\
& \ln P h r_{t}=\beta_{0}+\beta_{1} \ln P c i_{t}+\beta_{2} \ln G d p g r_{t}+\beta_{3} \ln L i t_{t}+\beta_{4} \ln G x p e_{t}+\beta_{5} \ln G x p h_{t}+\varepsilon_{t}
\end{aligned}
$$

where, in equations (2), (3), (5) and (6), $\alpha_{0}$ and $\beta_{0}$ are constant terms, $\mathrm{t}$ is time, while $\varepsilon$ is the error term. The apriori expectation is that a positive relationship is expected between per capita income and each of GDP growth rate, literacy rate, government expenditure on education and government expenditure on health. An individual negative impact is, however, expected on poverty headcount ratio from per capita income, GDP growth rate, literacy rate, government expenditure on education and government expenditure on health.

As regards econometric methodology, the cointegration approach offers useful insights towards testing for causal relationships. In principle, two or more variables are adjudged to be cointegrated when they share a common trend. Hence, the existence of cointegration implies that causality runs in at least one direction (Granger 1988). Thus, if two variables $X_{t}$ and $Y_{t}$ are non-stationary in their first differences, then they are I(1) series so that their linear combination would be

$$
Z_{t}=X_{t}-\lambda Y_{t}
$$

If $\lambda$ exists such that $Z_{t}$ is $\mathrm{I}(0)$, then their linear combination is stationary and are therefore cointegrated even though they may drift apart in the short run. As a first step in cointegration analysis, the study employed the both of Augmented Dickey Fuller (ADF) and Philips-Perron (P-P) unit root test statistics. Since the two tests give approximately the same output, the ADF is of the form,

$$
y_{t}=\alpha_{0}+\delta y_{t-1}+\alpha_{2} t+\sum_{i=1}^{p} \beta_{i}^{\prime} \prod y_{t-p}+\mu_{t}
$$

where $y_{t}$ is the variable being determined and the error term $\mu_{t}$ is of the form,

$$
\varepsilon\left(\mu_{t}\right)=0
$$

Essentially, the Johansen cointegration approach is adopted in this study. Unlike the Engle and Granger's two-step procedure, the Johansen technique avoids inserting the error term into the error correction mechanism. The procedure relies on the relationship between the rank of matrix and its characteristic roots and then estimates long-run relationship between non-stationary variables using maximum-likelihood procedure. Based on the rank of the coefficient matrix $\Pi$ of the equation, the test equation of the approach is of the form,

$$
\Delta X_{t}=\Gamma_{1} \Delta X_{t-1}+\Delta X_{t-2}+\ldots+\Gamma_{k-1} \Delta X_{t-p}+\prod X_{t-k}+\mu+\varepsilon_{t}
$$

where $X_{t}$ is a kx1 vector of $\mathrm{I}(1)$ variables of $\Gamma_{1}, \ldots, \Gamma_{k-1} . \Pi$ is kxk matrices of unknown parameters and contains information about the cointegrating relationship. Thus, in this case, the null hypothesis for $r$ cointegrating vector is that $\Pi$ has a reduced rank, $r<k$. The implication of the reduced rank is that the process $\Delta X_{t}$ is stationary and $X_{t}$ is non-stationary. If the rank of $\Pi$ is zero, there is no cointegrating vectors which implies absence of stationary combinations, if $\Pi$ is between $r$ and $k$, there exist $r$ cointegrating vectors and the $X$ variables are cointegrated. All the elements of $X$ would be stationary if $\Pi$ is of full rank. 
Further in the Johansen cointegration approach, the trace and maximum Eigen test statistics are specified respectively in (11) and (12) below as:

$$
\lambda_{\text {trace }}=-N \sum \ln \left(1-\lambda_{i+1}\right)
$$

and

$$
\lambda_{\max }(r, r+1)=-N \sum \ln \left(1-\lambda_{i+1}\right)
$$

where $\lambda_{i}$ is the estimated values of the characteristics roots generated from the $\Pi$ matrix, $r$ represents the number of cointegrating vectors, and $N$ equals the number of observations.

\section{Empirical Results and Discussion}

The results of the unit root test via the ADF and PP are jointly presented below in Table 2 where it shows that all the variables are stationary at first difference considering 1 per cent, 5 per cent and 10 per cent level of significance, respectively. Furthermore, the error correction mechanism (ECM) models, as shown by Table A3 and Table A4 in the appendix, reveal that the error correction term (ECT) is statistically significant with negative coefficient, as expected, in each of the models. The magnitude of the coefficients of the ECT implies that the series adjust quickly to equilibrium in case of any short-term disequilibrium. The series in model 2 would, however, adjust quickly than the series in model 1 due to a lower coefficient in the former.

As regards variables relationship, the first model depicts a statistically mixed relationship between per capita income and each of the variables. Essentially, a positive significant relation was reported between per capita income and GDP growth rate and government expenditure on health, while a negative statistically significant relationship was obtained with government expenditure on education. In the second model, however, a negatively statistical relationship was established between poverty headcount ratio and each of GDP growth rate, and government expenditure on health. Contrary to the apriori expectation, a positively significant relationship was obtained between per capita income and poverty headcount ratio.

Table 2. Augmented Dickey-Fuller and Phillips-Perron unit root tests on all variables

\begin{tabular}{clcccc}
\hline Variable & Stage & Critical Value & $1 \%$ & $5 \%$ & $10 \%$ \\
\hline Inphr & 1st Difference & -4.898979 & -2.660720 & -1.955020 & -1.609070 \\
lnpci & 1st Difference & -4.738992 & -2.664853 & -1.955681 & -1.608793 \\
lngdpgr & 1st Difference & -5.964880 & -2.664853 & -1.955681 & -1.608793 \\
lnlit & 1st Difference & -2.683977 & -2.660720 & -1.955020 & -1.609070 \\
lngxpe & 1st Difference & -7.322622 & -2.660720 & -1.955020 & -1.609070 \\
lngxph & 1st Difference & -6.231689 & -2.660720 & -1.955020 & -1.609070 \\
\hline
\end{tabular}

Source: Authors' Computation.

Thus, a hundred percentage point increase in the rate of growth of GDP, as well as in the government expenditure on health would respectively bring forth a 19.6 per cent and 21.9 per cent increase in the per capita income. Conversely, however, per capita income would drop by 1.9 per cent if there is a hundred percentage point rise in government expenditure on education. Furthermore, as per capita income rises by a hundred percentage point, poverty headcount ratio increases but by 9.4 per cent. Meanwhile, poverty headcount ratio in the country falls by 11 per cent, and 3.8 per cent respectively as GDP growth rate, and government expenditure on health increases individually by a hundred percentage point.

\section{Conclusion and Recommendations}

The poverty-inequality-economic growth nexus has been empirically examined by this study. Essentially, the study, on the one hand, investigated the effects of GDP growth rate, literacy rate, government expenditure on education, and government expenditure on health, on per capita income in Nigeria. On the other hand, the study further looked at the impacts of per capita income, growth rate of GDP, literacy rate, government expenditure on education, and government expenditure on health, on the poverty headcount ratio in the country. Results of the examination, therefore, reveal that GDP growth rate impacts positively on per capita income (inequality), but negatively on poverty headcount ratio. Yet, an increasing per capita income raises the poverty headcount ratio over the period considered. By implication, it shows that as the economy grows, the gap between the rich and the poor widens even though there is a slight improvement in the number of people moving to a level above USD 1.25 per day. It means that the growth is not inclusive as a considerably larger percentage of it is captured or 
enjoyed by those in the higher cadre of subgroups of the population (especially the people who are in the subgroup of the highest 20 per cent).

Essentially, as the study finds significant effects of GDP growth rate, government expenditure on education and government expenditure on health on per capita income and poverty headcount ratio, the government of Nigeria would need to boost the GDP by doing more in the area of domestic production of goods and services. More is, however, expected in the manufacture of non-oil exports as this would help boost income and the drive to self-reliance. Also, government should increase effective spending on education and public health facilities, and programmes that are meant primarily for the non-privileged like children, women and the poor in general. A healthy population means a wealthy nation. If the population is healthy and educated, there would be larger capacity for development and productivity which necessarily could translate to more growth with reduction in the levels of poverty and inequality in the country.

\section{References}

Adams, R. H. Jr. (2004). Economic Growth, Inequality and Poverty: Estimating the Growth Elasticity of Poverty. World Development, 32, 1989-2014. http://dx.doi.org/10.1016/j.worlddev.2004.08.006

Addison, A., \& Comia, G. A. (2001). Income Distribution Policies for faster Poverty Reduction. UNU-WIDER Discussion Paper No. 2001/93 (September).

African Economic Outlook. (2012). Nigera 2012. Retrieved from http://www.africaneconomicoutlook.org

Ahituv, A., \& Moav, O. (2003). Fertility clubs and economic growth. In Eicher, T. S., \& Turnovsky, S. J. (Eds.), Inequality and Growth: Theory and Policy Implications (pp. 61-87). Cambridge, London: MIT Press.

Aigbokhan, B. E. (2008). Growth, Inequality and Poverty in Nigeria. Economic Commission for Africa. ACGS/MPAMS Discussion Paper No. 3, UNECA, Addis Ababa, Ethiopia.

Alesina, A., \& Perotti, R. (1996). Income distribution, political instability, and investment. European Economic Review, 40(6), 1203-1228. http://dx.doi.org/10.1016/0014-2921(95)00030-5

Alesina, A., \& Rodrik, D. (1994). Distributive politics and economic growth. Quarterly Journal of Economics, 109(2), 465-490. http://dx.doi.org/10.2307/2118470

Ali, S. S., \& Tahir, S. (1999). Dynamics of growth, poverty and inequality in Pakistan. Pakistan Development Review, 38(4), 337-858.

Anyanwu, J. C. (1997). Poverty in Nigeria: Concepts and Measurement and Determinants (pp. 93-120). In the Annual Conference Proceedings of The Nigeria Economic Society (NES): Poverty in Nigeria.

Anyanwu, J. C., \& Erhijakpor, A. E. O. (2010). Do International Remittances Affect Poverty in Africa? African Development Review, 22(1), 51-91. http://dx.doi.org/10.1111/j.1467-8268.2009

Atkinson, A. (1997). Bringing Income Distribution in from the Cold. Economic Journal, 107(441), $297-321$. http://dx.doi.org/10.1111/j.0013-0133

Badiane, O., \& Ulimwengu, J. (2009). The Growth-Poverty Convergence Agenda: Optimizing Social Expenditures to Maximize Their Impact on Agricultural Labour Productivity, Growth, and Poverty Reduction in Africa. IFPRI Discussion Paper 00906.

Barro, R. J. (2000). Inequality and growth in a panel of countries. Journal of Economic Growth, 5(1), 5-32. http://dx.doi.org/10.1023/A:1009850119329

Birdsall, N., Ross, D., \& Sabot, R. (1995). Inequality and Growth Reconsidered: Lessons from East Asia. World Bank Economic Review, 9, 477-508. http://dx.doi.org/10.1093/wber/9.3.477

Bourguignon, F. (2004). The Poverty-Growth-Inequality Triangle. Paper presented at the Indian Council for Research on International Economic Relations, New Delhi, on February 4.

Castello, A., \& Domenech, R. (2002). Human capital inequality and economic growth: Some new evidence. Economic Journal, 112(478), 187-200. http://dx.doi.org/10.1111/1468-0297

Castello-Climent, A. (2004). A Reassessment Of The Relationship Between Inequality And Growth: What Human Capital Inequality Data Say? Instituto Valenciano de Investigaciones Economicas.

Central Bank of Nigeria. (2013). Statistical Bulletin. Retrieved from http://www.centralbankofnigeria.gov.ng

Charles-Coll, J. A. (2013). The Debate Over the Relationship Between Income Inequality and Economic Growth: Does Inequality Matter for Growth? Research in Applied Economics, 5(2), 1-18. 
http://dx.doi.org/10.5296/rae.v5i2.3361

Cheema, A. R., \& Sial, M. H. (2012). Poverty, Income Inequality, and Growth in Pakistan: A Pooled Regression Analysis. The Lahore Journal of Economics, 17(2), 137-157.

Clarke, G. R. G. P. (1995). More evidence on income distribution and growth. Journal of Development Economics, 47(2), 403-427. http://dx.doi.org/10.1016/0304-3878(94)00069-O

Dauda, R. O. S. (2004). Poverty, Inequality and Socio-Economic Development Policies in Nigeria." In Fakiyesi \& Akano (Eds.), Issues in Money, Finance and Economic Management in Nigeria: Essays in Honour of Obasanmi Olakanpo. Department of Economics, University of Lagos.

Davis, L. S. (2007). Explaining the evidence on inequality and growth: Informality and Redistribution. $B E$ Journal of Macroeconomics, 7(1). http://dx.doi.org/10.2202/1935-1690.1498

De la Croix, D., \& Doepke, M. (2003). Inequality and growth: Why differential fertility matters. American Economic Review, 93(4), 1091-1113. http://dx.doi.org/10.1257/000282803769206214

Deininger, K., \& Squire, L. (1996). A new data set measuring income inequality. World Bank Economic Review, 10(3), 565-591. http://dx.doi.org/10.1093/wber/10.3.565

Deolalikar, A. B. (2002). Poverty, Growth and Inequality in Thailand Manila, the Philippines. Working Paper No. 8, Economics and Research Department, Asian Development Bank.

Dickey, D. A., \& Fuller, W. A. (1979). Distribution of the Estimators for Autoregressive Time Series with a Unit Root. Journal of the American Statistical Association, 74, 427-431.

Fan, S., Yu, B., \& Jitsuchon, S. (2008a). Does Allocation of Public Spending Matter in Poverty Reduction? Evidence from Thailand. Asian Economic Journal, 22(4), 411-430. http://dx.doi.org/10.1111/j.1467-8381

Fan, S., Yu, B., \& Saurka, A. (2008b). Public Spending in Developing Countries: Trends, Determination, and Impact. In Fan (Ed.), Public Expenditures, Growth and Poverty: Lessons from Developing Countries. International Food Policy Research Institute.

Forbes, K. J. (2000). A reassessment of the relationship between inequality and growth. American Economic Review, 90(4), 869-887. http://dx.doi.org/10.1257/aer.90.4.869

Fosu, A. K. (2009). Inequality and the impact of growth on poverty: Comparative evidence for Sub-Saharan Africa. Journal of Development Studies, 45(5), 726-745. http://dx.doi.org/10.1080/00220380802663633

Galor, O., \& Zeira, J. (1993). Income Distribution and Macroeconomics. Review of Economic Studies, 60, 35-52. http://dx.doi.org/10.2307/2297811

Ghosh, S., \& Pal, S. (2004). The Effect of Inequality on Growth: Theory and Evidence from the Indian States. Review of Development Economics, 8(1), 164-177. http://dx.doi.org/10.1111/j.1467-9361

Granger, C. W. J. (1988). Some Recent Development in a Concept of causality. Journal of Econometrics, 39, 199-211. http://dx.doi.org/10.1016/0304-4076(88)90045-0

Gregorio, J., \& Lee, J. (2002). Education and Income Inequality: New Evidence form Cross-Country Data. Review of Income and Wealth. Series, 48(3), 395-416. http://dx.doi.org/10.1111/1475-4991.00060

Josten, S. D. (2003). Inequality, crime and economic growth: A classical argument for distributional equality. International Tax and Public Finance, 10(4), 435-452. http://dx.doi.org/10.1023/A:1024683431555

Josten, S. D. (2004). Social Capital, Inequality, and Economic Growth. Journal of Institutional and Theoretical Economics, 160(4), 663-680. http://dx.doi.org/10.1628/0932456042776087

Kakwani, N. (1993). Poverty and Economic Growth With Application to Côte D'Ivoire. Review of Income and Wealth, 39, 121-139. http://dx.doi.org/10.1111/j.1475-4991.

Kaldor, N. (1956). Alternative theories of distribution. Review of Economic Studies, 23, 83-100. http://dx.doi.org/10.2307/2296292

Kanbur, R. (2008). Poverty and Distribution: Twenty Years Ago and Now. Paper presented at the 3rd African Economic Conference, African Development Bank, Tunis, November.

Kim, J. Y. (2014). Nigeria: World Bank - Extreme Income Inequality, Disincentive to Poverty Reduction. Retrieved from http://allafrica.com/stories/201404110500.html

Knowles, S. (2005). Inequality and economic growth: The empirical relationship reconsidered in the light of comparable data. Journal of Development Studies, 41(1), 135-159. 
http://dx.doi.org/10.1080/0022038042000276590

Kolawole, B. O., \& Omobitan, O. A. (2014). Raging Poverty and Agricultural Output in Nigeria: An Empirical Investigation. Journal of Economics and Sustainable Development, 5(6), 63-72.

Kurita, K., \& Kurosaki, T. (2007). Dynamics of Growth, Poverty, and Inequality: Panel Analysis of Regional Data from the Philippines and Thailand. The Institute of Economic Research.

Lee, W., \& Roemer, J. E. (1998). Income Distribution, Redistributive Politics, and Economic Growth. Journal of Economic Growth, 3(3), 217-240. http://dx.doi.org/10.1023/A:1009762720862

Li, H., \& Zou, H. F. (1998). Income Inequality Is Not Harmful for Growth: Theory and Evidence. Review of Development Economics, 2(3), 318-334. http://dx.doi.org/10.1111/1467-9361.00045

Lombardo, V. (2008). Growth and Inequality effects on Poverty reduction in Italy. Discussion Paper No. 9, Department of Economic Studies, University of Naples, Italy.

Magnowski, D. (2014). Nigeria Overtaking South Africa Masks Poverty Trap: Economy. Retrieved from http://www.bloomberg.com/news/2014-03-17/Nigeria-overtaking-south-africa-s-economy-masks-poverty-tr ap.html

Nahum, R. A. (2005). Income Inequality and Growth: A Panel Study of Swedish Counties 1960-2000. Arbetsrapport, Institute for Futures Studies.

Ncube, M., Anyanwu, J., \& Hausken, K. (2013). Inequality, Economic Growth, and Poverty in the Middle East and North Africa (MENA). African Dev Bank, Working Paper Series No. 195.

Ndubuisi, F. (2014). Nigeria: World Bank-Extreme Income Inequality, Disincentive to Poverty Reduction. Retrieved from http://allafrica.com/stories/201404110500.html

Panizza, U. (2002). Income inequality and economic growth: Evidence from American data. Journal of Economic Growth, 7(1), 25-41. http://dx.doi.org/10.1023/A:1013414509803

Partridge, M. D. (1997). Is inequality harmful for growth? Comment. American Economic Review, 87(5), 10191032.

Pede, V. O., Florax, R. J. G. M. P., \& Partridge, M. D. P. (2009). Employment Growth and Income Inequality: Accounting for Spatial and Sectoral Differences. Agricultural and Applied Economics Association.

Perotti, R. (1993). Political equilibrium, income distribution and economic growth. Review of Economic Studies, 60(4), 755-776. http://dx.doi.org/10.2307/2298098

Persson, T., \& Tabellini, G. (1994). Is inequality harmful for growth? American Economic Review, 84(3), 600621.

Ram, R. (2007). Roles of income and equality in poverty reduction: Recent cross-country evidence. Journal of International Development, 19, 919-926. http://dx.doi.org/10.1002/jid.1348

Ravallion, M. (1997). Can high-inequality developing countries escape absolute poverty? Economic Letters, 56(1), 51-57. http://dx.doi.org/10.1596/1813-9450-1775

Ravallion, M., \& Chen, S. (1997). What can new survey data tell us about recent changes in distribution and poverty? World Bank Economic Review, 11(2), 357-382. http://dx.doi.org/10.1093/wber/11.2.357

Ravallion, M., Chen, S., \& Sangraula, P. (2008). Dollar a Day Revisited. Development Research Group, World Bank 1818 H Street NW, Washington DC, 20433, USA. http://dx.doi.org/10.1596/1813-9450-4620

Son, H. (2007). Interrelationship between Growth, Inequality, and Poverty: The Asian Experience. Asian Development Review, 24(2), 37-63. http://dx.doi.org/10.1.1.177.2133

Son, H., \& Kakwani, N. (2004). Economic growth and poverty reduction: Initial conditions matter. Working Paper No. 2, Brasilia: United Nations Development program.

United Nations Economic Commission for Africa. (2007). Economic Report on Africa 2007: Accelerating Africa's Development through Diversification. Economic Commission for Africa, Addis Ababa, Ethiopia. Retrieved from http://www.uneca.org/sites/default/files/publications/era2007full.pdf

Viaene, J. M., \& Zilcha, I. (2003). Human capital formation, income inequality, and growth. Theory and Policy Implications, 89-117.

White, H., \& Anderson, E. (2001). Growth versus Distribution: Does the Pattern of Growth Matter? Development Policy Review, 19, 267-289. http://dx.doi.org/10.1111/1467-7679.00134 
Wodon, Q. T. (1999). Growth, poverty and inequality: A regional panel for Bangladesh. Policy Research Working Paper No. 2072, World Bank, Washington, DC. http://dx.doi.org/10.1596/1813-9450-2072

World Bank. (2001). World Development Report 2000/2001: Attacking Poverty. The International Bank for Reconstruction and Development / The World Bank. Washington, D.C. 20433, U.S.A.

World Bank. (2014). Nigeria-Income Distribution. Retrieved from http://iresearch.worldbank.org/PovcalNet/index.htm.

\section{Appendix A}

Table A1. Lag length selection criteria

\begin{tabular}{ccccccc}
\hline \multicolumn{6}{l}{ Endogenous variables: LNPCI, LNGDPGR, LNLIT, LNGXPE, LNGXPH } \\
\hline Lag & LogL & LR & FPE & AIC & SC & HQ \\
0 & 125.2259 & NA & $4.58 \mathrm{e}-11$ & -9.618069 & -9.374294 & -9.550456 \\
1 & 265.8253 & $213.7111^{*}$ & $4.62 \mathrm{e}-15$ & -18.86602 & -17.40337 & -18.46034 \\
2 & 298.8427 & 36.97957 & $3.20 \mathrm{e}-15^{*}$ & $-19.50742^{*}$ & $-16.82589^{*}$ & $-18.76368^{*}$ \\
\hline
\end{tabular}

Table A2. Output of the Johansen cointegration approach

\begin{tabular}{ccccc}
\hline Hyp. No & Eigenvalue & Trace Stat & $5 \%$ C.V. & Prob. \\
\hline $\mathrm{r}=0$ & 0.990537 & 88.54728 & 40.07757 & 0.0000 \\
$\mathrm{r} \leq 1$ & 0.953681 & 58.37177 & 33.87687 & 0.0000 \\
$\mathrm{r} \leq 2$ & 0.926542 & 49.60988 & 27.58434 & 0.0000 \\
$\mathrm{r} \leq 3$ & 0.581133 & 16.53381 & 21.13162 & 0.1952 \\
$\mathrm{r} \leq 4$ & 0.362942 & 8.566994 & 14.2646 & 0.3240 \\
$\mathrm{r} \leq 5$ & 0.175019 & 3.655508 & 3.841466 & 0.0559 \\
\hline
\end{tabular}

Table A3. The parsimonious (error correction) model 1

\begin{tabular}{ccccc}
\hline \multicolumn{2}{l}{ Dependent Variable: D(LNPCI) } & & & \\
\hline Variable & Coefficient & Std. Error & t. Statistic & Prob. \\
D(LNGDPGR) & 0.196802 & 0.095724 & 2.074376 & 0.0631 \\
D(LNGXPE) & -0.0198 & 0.049976 & -1.59065 & 0.0925 \\
D(LNGXPH) & 0.219465 & 0.047458 & 2.161365 & 0.0524 \\
ECT(-1) & -0.81832 & 0.195786 & -3.39515 & 0.0028 \\
\hline Adj. R2: 0.478261 & DW: 1.890275 & & & \\
\hline
\end{tabular}

Table A4. The parsimonious (error correction) model 2

\begin{tabular}{ccccc}
\hline Dependent Variable: D(LNPHR) & & & & \\
\hline Variable & Coefficient & Std. Error & t. Statistic & Prob. \\
D(LNPCI) & 0.094213 & 0.088247 & 2.066551 & 0.0565 \\
D(LNGDPGR $)$ & -0.22017 & 0.063665 & -1.7827 & 0.0832 \\
D(LNGXPH) & -0.03874 & 0.016622 & -3.25334 & 0.0041 \\
ECT(-1) & -0.71751 & 0.194794 & -3.39375 & 0.0013 \\
\hline Adj. R2: 0.480712 & DW: 1.922082 & & & \\
\hline
\end{tabular}

\section{Copyrights}

Copyright for this article is retained by the author(s), with first publication rights granted to the journal.

This is an open-access article distributed under the terms and conditions of the Creative Commons Attribution license (http://creativecommons.org/licenses/by/3.0/). 